\title{
Controlled-Release Fertilizer Opportunities and Costs for Potato Production in Florida ${ }^{1}$
}

\section{Chad M. Hutchinson and Eric H. Simonne ${ }^{2}$}

The recent emphasis on the development of vegetable production Best Management Practices has prompted a re-examination of fertilization practices in Florida potato production. One fertilizer practice that can meet the production and environmental goals of both growers and regulatory agency personnel is the use of controlled-release fertilizers (CRFs). CRFs are polymer coated nitrogen $\mathrm{N}$ fertilizers, typically urea, that are engineered to release nutrients based on soil temperature and not soil moisture. This release profile decreases the $\mathrm{N}$ leaching potential of the fertilizer. IFAS research over the past three years has demonstrated that $\mathrm{N}$ rates can be reduced with a CRF program compared to a soluble $\mathrm{N}$ fertilizer program (non-coated urea and/or ammonium nitrate) without reducing crop yield or quality. Although CRF technology can improve $\mathrm{N}$ use efficiency, the high cost of the material has limited the adoption of CRF technology in potato production. However, the development of BMPs coupled with the cost-share potential of CRFs at the national, state and/or local level has improved the chance that CRFs will be used as a fertilizer source for potato production.

The objective of this article is to compare the costs and benefits of a nitrogen CRF program to a traditional soluble $\mathrm{N}$ program in potato. The cost of a soluble $\mathrm{N}$ fertilizer program varies between growers and over years based on manufacturing costs, $\mathrm{N}$ sources, and rate. Therefore, a range of possible costs and rates are detailed in Table 1. The BMP N rate for a soluble program is $200 \mathrm{lb}$ N/acre and is included for comparison. In Table 2, several cost and rate combinations for a CRF program are listed. There are several unknowns with the CRF program. The most important of which is material cost per ton.

\section{Soluble Nitrogen Source}

Highlighted in Table 1 are combinations of common costs and rates for a soluble $\mathrm{N}$ program in northeastern Florida over the past few years. Highlighted N costs range from 2.1 to $3.5 \%$ of the total production cost for potato $(\$ 1800$ total production cost). To find the $\mathrm{N}$ cost for a specific farm or program, locate the cost of $\mathrm{N}$ per acre for the previous season at the top of the chart and move down the column to the appropriate nitrogen fertilizer rate.

\section{CRF Nitrogen Source}

Current IFAS research indicates that tuber quality and yield with a CRF program of 150 to 175

1. This document is HS941, one of a series of the Horticultural Sciences Department, Florida Cooperative Extension Service, Institute of Food and Agricultural Sciences, University of Florida. Publication date: July 2003. Please visit the EDIS Web site at http://edis.ifas.ufl.edu.

2. Chad M. Hutchinson, assistant professor, Eric H. Simonne, assistant professor, Horticultural Sciences Department, Cooperative Extension Service, Institute of Food and Agricultural Sciences, University of Florida, Gainesville, 32611.

The Institute of Food and Agricultural Sciences is an equal opportunity/affirmative action employer authorized to provide research, educational information and other services only to individuals and institutions that function without regard to race, color, sex, age, handicap, or national origin. For information on obtaining other extension publications, contact your county Cooperative Extension Service office. Florida Cooperative Extension Service/Institute of Food and Agricultural Sciences/University of Florida/Christine Taylor Waddill, Dean. 
lb N/acre are comparable to a standard soluble fertilizer program at the BMP rate (200 lb N/acre). CRF prices used here are based on discussions with industry personnel. To be competitive, however, products should be priced between $\$ 400$ and $\$ 700 /$ ton. Therefore, the projected cost of $\mathrm{N}$ from a CRF program ranges from 3.9 to $7.8 \%$ of the total production costs for potato $(\$ 1,800$ total production cost) (Table 2).

\section{Discussion}

Tables 1 and 2 list the potential grower costs for the soluble and CRF fertilizer programs. The most expensive highlighted CRF program ( $\$ 142 /$ acre) is 3.7 to 2.3 times more expensive than the least and most expensive highlighted soluble fertilizer programs (\$38 and \$63/acre), respectively. There are, however, several benefits to using a CRF program that may offset some of the cost of the CRF program. The benefits of a CRF program compared to a soluble fertilizer program include:

1. A CRF program requires a single, pre-plant, fertilizer application compared to multiple applications (application number dependent on season) with a soluble fertilizer program. The BMP program recommends at least a single split application (2 trips) when using soluble $\mathrm{N}$ sources. Each trip across the field costs approximately $\$ 3 /$ acre.

2. A polymer coated CRF releases nutrients based on soil temperature and not soil moisture.

Therefore, during potato seasons with substantial rain, $\mathrm{N}$ in the CRF prill will remain in the field and not leach into the watershed. The current BMPs for the soluble fertilizer program allow up to $30 \mathrm{lb}$ N/acre to be added during the season after each leaching rain event to make-up for leaching. In the 2003 season, some growers applied an extra $90 \mathrm{lb}$ N/acre as part of the BMP program because of the substantial rainfall (total $290 \mathrm{lb}$ N/acre for BMP program in 2003). No added $\mathrm{N}$ was necessary with the CRF program (150 to 175 N/acre in 2003).

3. The CRF program improves $\mathrm{N}$ use efficiency as alluded to above (2). A higher percentage of applied $\mathrm{N}$ makes it into the crop when fertilized with a CRF compared to a soluble fertilizer source. This is because CRFs release $\mathrm{N}$ slowly over the season as the crop needs it. Therefore, there is less opportunity for $\mathrm{N}$ to leach into the watershed with a CRF program. CRF $\mathrm{N}$ rates of 175 and $150 \mathrm{lb} /$ acre translate into a yearly $\mathrm{N}$ savings of 450,000 to $900,000 \mathrm{lb}$ in the St. Johns River watershed production area compared to the BMP nitrogen rate. By reducing the $\mathrm{CRF} N$ rate below the BMP rate, growers and manufactures can develop good will with the public while reducing the potential for nitrate to enter the watershed.

4. The CRF program improves operational efficiencies. With limited trips through the field to apply fertilizer and reduced worry during rainy seasons, growers can spend more time doing other things such as marketing potatoes.

CRF is more expenxive than a traditional soluble fertilizer on a per unit basis. However, Florida citizens and growers would benefit if CRF costs were shared by all parties that have a stake in improving water quality in the St. Johns River watershed. In this simple model, the cost of a soluble $\mathrm{N}$ fertilizer program in most years falls between $\$ 38$ to $\$ 63 /$ acre (Table 1). Estimated CRF program costs (highlighted in Table 2) would be approximately $\$ 8$ to $\$ 79 /$ acre more than the most expensive soluble $\mathrm{N}$ cost (\$63/acre, Table 1). If this cost difference was supported $100 \%$ by local, state or national regulatory agency funds, the cost-share program would require $\$ 144,000$ to $\$ 1,422,000$ annually to be fully funded. The northeast Florida potato crop is valued at approximately $\$ 60$ to 75 million. The cost share program costs would be a relatively small cost to keep a northeast Florida business with a potential $\$ 75$ million dollar annual return solvent.

These numbers serve as a starting point for discussion regarding the value of using CRFs in potato production in the St. Johns River watershed. There are approximately 18,000 acres of potatoes in the St. Johns River watershed that can benefit from a $\mathrm{CRF}$ program. In addition, there are well over 100,000 acres of other vegetable crops on seepage irrigation across Florida that could benefit from a CRF program. This acreage increases greatly if one considers all the production areas in the U.S. where $\mathrm{N}$ 
may be negatively impacting surrounding watersheds.

A CRF program can be a win-win-win opportunity for growers, manufacturers, and regulatory agencies by helping all meet their production, business, and environmental goals.

\section{Additional Information}

Hutchinson, C.M., W.A. Tilton, and E.H. Simonne. 2002. On-farm demonstration of a controlled release fertilizer program for potato production. Vegetarian Newsletter, Horticultural Sciences Department, University of Florida. June. http://www.hos.ufl.edu/vegetarian/02/June/June.htm

Hutchinson, C.M. and E.H. Simonne. 2002. Development of controlled release fertilizer program for potato production. Vegetarian Newsletter, Horticultural Sciences Department, University of Florida. March.

http://www.hos.ufl.edu/vegetarian/02/March/

Mar02.htm 
Table 1. Traditional soluble fertilizer program costs per acre using a blend of urea and ammonium nitrate with a final grade of 32-0-0.

\begin{tabular}{|c|c|c|c|c|c|c|}
\hline \multirow{2}{*}{$\begin{array}{l}\text { Rate } \\
\text { (lb N/a) }\end{array}$} & \multicolumn{5}{|c|}{$\begin{array}{l}\text { Soluble Fertilizer Cost (per acre) } \\
{\text { (\$/ton product })^{z}}\end{array}$} & \multirow{2}{*}{$\begin{array}{c}\% \text { Total } \\
\text { Production Costs }\end{array}$} \\
\hline & 130 & 140 & 150 & 160 & 170 & \\
\hline 150 & 31 & 33 & 35 & 38 & 40 & \\
\hline 175 & 36 & 38 & 41 & 44 & 47 & $2.1-2.4$ \\
\hline 200 & 41 & 44 & 47 & 50 & 53 & $2.4-2.8$ \\
\hline 225 & 46 & 49 & 53 & 56 & 60 & $2.7-3.1$ \\
\hline 250 & 51 & 55 & 59 & 63 & 66 & $3.1-3.5$ \\
\hline 275 & 56 & 60 & 64 & 69 & 73 & \\
\hline 300 & 61 & 66 & 70 & 78 & 80 & \\
\hline
\end{tabular}

Table 2. Alternative CRF program costs per acre using a polymer coated urea with a final grade of 43-0-0.

\begin{tabular}{|c|c|c|c|c|c|c|c|}
\hline \multirow{2}{*}{$\begin{array}{l}\text { Rate } \\
\text { (lb N/a) }\end{array}$} & \multicolumn{6}{|c|}{$\begin{array}{l}\text { CRF Cost (per acre) } \\
\left(_{(\$ / \text { ton product })^{2}}\right.\end{array}$} & \multirow{2}{*}{$\begin{array}{c}\% \text { Total } \\
\text { Production Costs }\end{array}$} \\
\hline & 300 & 400 & 500 & 600 & 700 & 800 & \\
\hline 125 & 44 & 59 & 73 & 88 & 101 & 116 & \\
\hline 150 & 53 & 71 & 87 & 105 & 122 & 140 & 3.96 .7 \\
\hline 175 & 61 & 82 & 102 & 123 & 142 & 163 & 4.67 .8 \\
\hline 200 & 70 & 94 & 116 & 140 & 162 & 186 & \\
\hline 225 & 79 & 105 & 130 & 157 & 183 & 209 & \\
\hline
\end{tabular}

